УДК 159.922

DOI https://doi.org/10.32838/2709-3093/2021.3/15

Ткачишина О.P.

Київський університет імені Бориса Грінченка

\title{
ОСОБЛИВОСТІ СОЦІАЛЬНО-ПСИХОЛОГІЧНОЇ АДАПТАЦІї ОСОБИСТОСТІ В УМОВАХ КРИЗОВИХ СИТУАЦЙ
}

Стаття присвячена проблемі сочіально-психологічної адаптації особистості в умовах кризових ситуацій. Проблема соиіально-психологічної адаптащії особистості на сучасному етапі розвитку суспільства є актуальною і буде залишатись такою, оскільки змінюється світ, у якому ми жсивемо, змінюється людське суспільство, зрештою, змінюється особистість. Особистісні зміни значною мірою зумовлені процесом соиіально-психологічної адаптації особистості до суспільних трансформацій та перетворень, що є особливо важливим в умовах кризових ситуачій. Життя сучасної особистості характеризується насиченістю, неоднорідністю та мінливістю, що породжує деякі психологічні труднощі в житті. Сучасний соиіум розмиває почуття надійності, захищеності та впевненості в завтрашньому дні. Людина змушена адаптуватися до нових умов та вимог, щяо висувають до неї соиіум, наука, техніка. В останні десятиліття завдяки науково-технічному прогресу ичі зміни стають дуже швидкими. Крім того, вони роблять сочіум більш агресивним щодо людини. Соиіальні взаємодії часто є головним джерелом серйозних конфліктів та стресу для людини і можуть негативно впливати на фізичне та психічне здоров'я. Сучасне жсття насичене різними стресогенними чинниками, що впливають як на фізичне, так і на психічне здоров'я людини, а тривале перебування у стресових ситуачіях може призвести до життєвої кризи. Особистість постає перед необхідністю долати стреси, розв 'язувати проблеми, вирімувати складні завдання, які ставить перед нею саме життя. У статті розкрита психологічна характеристика кризових ситуацій, кризових станів, визначено основний зміст кризи загалом. Визначено основні чинники, що виливають на особливості соиіально-психологічної адаптації особистості у кризовій ситуації. Наголошується на важливості активізаиії адаптаційних ресурсів особистості у кризових ситуачіях життя. Важливу роль у иьому контексті відіграють індивідуальнопсихологічні особливості особистості, ї̈ життєвий досвід, знання, що мають вирімальне значення у виробленні конструктивних копінг-стратегій подолання кризових ситуацій.

Ключові слова: сочіально-психологічна адаптація, криза, кризові ситуації, кризові стани, адаптаиійні ресурси.

Постановка проблеми. Проблема соціальнопсихологічної адаптації в різних іiі проявах $\epsilon$ однією 3 найактуальніших у науці та суспільній практиці, особливої актуальності вона набуває у кризовій ситуації, коли особистість переживає важкі життєві обставини, змушена пристосовуватись до зміненої реальності, нової соціальної дійсності тощо. В умовах сучасного розвитку суспільства збільшується кількість негативних впливів на людину, які вона не завжди спроможна опанувати, конструктивно на них відреагувати або адаптуватися до них. Такий вплив безпосередньо позначається на психічному стані особистості. Соціальна дійсність, як політична, так і економічна, нерідко стає для особистості потужним стресогенним чинником, а довготривалий стрес зазвичай виступає провокатором життєвої кризи. Сучасні соціальні, екологічні, медичні й інші проблеми, що є актуальними в Україні, актуалізують проблеми кризових ситуацій, реагування на них, їх переживання та подолання. Загальновизнаним $€$ факт неминучості криз у житті людини і навіть необхідності переживання емоційно складних життєвих обставин у контексті розвитку особистості, іï зростання та самоздійснення (Л. Анциферова, Р. Ахмеров, Ф. Василюк, С. Гроф, Є. Донченко, Л. Регуш, Т. Титаренко й інші). Немає людини, яка б не знала із власного досвіду, що таке криза, оскільки всі ми змінюємось, дорослішаємо, переживаємо кризи розвитку, стикаємось iз різними труднощами життя, непереборними обставинами, які вимагають від людини включення адаптаційних резервів із метою пристосування до зміненої реальності [4].

Аналіз останніх досліджень і публікацій. Проблема соціально-психологічної адаптації особистості досить широко висвітлена в роботах науковців. Досліджувались, зокрема, уявлення про 
адаптацію, ії закономірності та механізми загалом (Г. Балл, Ф. Березін, В. Казначеєв, Ф. Меєрсон, О. Налчаджян та інші), про адаптацію як форму соціальної активності особистості (В. Семиченко, О. Солодухова й інші); загальні проблеми соціально-психологічної адаптації особистості (Б. Ананьєв, Г. Балл, Л. Виготський, О. Леонтьєв, В. Петровський, А. Фурман та інші); формування і розвиток адаптивних характеристик особистості (А. Алдашева, Н. Кантоністова, Н. Колизаєва, Т. Середа й інші); теорії саморегуляції функціональних та психічних станів особистості, iï поведінки та діяльності (К. Абульханова-Славська, Л. Балабанова, О. Конопкін, А. Леонова, В. Моросанова й інші).

Постановка завдання. Метою статті $є$ психологічний аналіз кризових ситуацій та визначення чинників, що впливають на особливості соціально-психологічної адаптації особистості у кризовій ситуації.

Виклад основного матеріалу дослідження. Поняття соціально-психологічної адаптації можна визначити як багатоплановий процес активного пристосування психіки та поведінки особистості до умов соціального середовища, яке опосередковане провідною діяльністю особистості на даному етапі iї розвитку. У процесі соціально-психологічної адаптації змінюється і внутрішній світ людини: 3'являються нові уявлення, знання про діяльність, якою вона займається, у результаті чого відбуваються самокорекція і самовизначення особистості. Щодо проблеми кризових ситуацій життя, то серед науковців немає одностайності щодо даного питання. У сучасних вітчизняних і закордонних дослідженнях, що стосуються проблеми кризових ситуацій життя, уживається різнобічна епістемологічна й етимологічна термінологія. Наприклад, у межах напряму «психологія життєвого шляху» (Б. Ананьєв, С. Рубінштейн) «кризова ситуація життя» розглядається як «подія життєвого шляху», що є для особистості поворотним етапом, на якому ухвалюються важливі рішення щодо подальшого життя. В інших теоріях споріднені поняття трактуються так: як «важка життєва ситуація» (Л. Анциферова), «ситуація соціальної нестабільності» (К. Василевська), «духовна криза» (С. Гроф), «криза» (Е. Еріксон, Д. Маттесон), «психотравмувальна ситуація» (Т. Кириленко), «критична ситуація» (Е. Крупник), «критичний стан буття» (I. Маноха), «значуща ситуація» (В. Мясищев), «життєва криза» (Т. Титаренко) тощо [8].
Кризові стани та критичні ситуації, що їх зумовлюють, потребують пильної уваги й аналізу, оскільки від цього залежить включення адаптаційних ресурсів особистості з метою їх розв'язання та подолання. Кризові стани особистості характеризуються високим рівнем нервово-психічної напруги аж до перенапруги і психічного виснаження. Важливими ознаками кризових станів особистості $\epsilon$ високий рівень тривоги, депресії, почуття безпорадності, апатії, суму, гніву, фізичного стомлення, зниження самооцінки, сенситивність, а також наявність психологічної фрустрації як нездоланної перешкоди або життєвої ситуації. Психологічно кризовий стан особистості характеризується інтенсивними негативними емоціями: почуттям невизначеності, занепокоєнням, тривогою аж до дезорганізації, фіксацією на психотравмувальній ситуації, переживаннями власної безпорадності, неспроможності, самотності, безнадійності, песимістичною оцінкою власної особистості, актуальної ситуації й життєвої перспективи, вираженими утрудненнями у плануванні майбутнього [3].

«Кризовою» називають ситуацію, коли людина стикається 3 перешкодою в реалізації важливих життєвих цілей і не може впоратися із цією ситуацією за допомогою звичних засобів. Виділяються два типи кризових ситуацій: зумовлені змінами у природному життєвому циклі або травмувальними подіями життя [7]. Отже, критична ситуація - це така ситуація, у якій суб'єкт не може реалізувати основні потреби свого життя, яка ставить його перед необхідністю зміни способу буття. А криза - це реакція особистості на критичну ситуацію, що виражається в нездатності особистості розв'язати цю ситуацію в короткий час і звичний спосіб. У гострий (або початковий) період кризової ситуації людина мислить стереотипно, тобто шаблонно. Звужуються свідомість та раціональна сфера особистості, що перешкоджає об'єктивній оцінці ситуації та пошуку адекватного рішення, натомість превалюють емоції, що здебільшого мають полярний характер.

Необхідно підкреслити, що у кризовій, критичній ситуації життя відбувається активізація стереотипів, що здійснюється завдяки процесу соціально-психологічної адаптації особистості до змінених обставин та соціальної дійсності. Об'єктивним результатом явища стереотипізації у кризовій ситуації є спрощене, схематичне, інколи близьке до істинного, інколи викривлене уявлення дійсності, що виражається в певних стереотипах. У даному контексті варто згадати деякі важливі функції стереотипів, як-от: класифікація й 
упорядкування соціокультурної інформації; вироблення моделей поведінки та стандартів; захист групових цінностей; економія зусиль у повсякденному мисленні; заощадження часу під час сприйняття нового та сприяння успішній соціально-психологічній адаптації особистості [8].

I теоретики, і практики вважають, що в ситуації кризи під час спроби оволодіння стресовим станом людина переживає певний вид фізичного та психологічного перевантаження. Емоційне напруження і стрес можуть призводити або до опанування нової ситуації (це так звані копінгстратегіï), або до зриву і погіршення виконання життєвих функцій. Хоча деякі ситуації можуть бути стресовими для всіх людей, вони виявляються кризами для тих, хто є особливо чутливим через індивідуально-особистісні особливості. Необхідною умовою виникнення кризи є значні емоційні навантаження, блокування найважливіших потреб індивіда та його специфічна особистісна реакція на це [6]. Кризові ситуації і кризи різноманітні, як саме життя людини. Психологи виділяють такі основні кризи, 3 якими стикається практично кожна людина протягом життя: кризи розвитку (вікові кризи); деприваційні кризи (кризи втрати і розлуки); травматичні кризи; кризи відносин; кризи сенсу життя; моральноетичні кризи [1]. Крім вікових, нормативних криз, кожному знайомі й інші кризи, ненормативні, які частіше називають життєвими. Вони виникають у складних життєвих обставинах, коли людина опи-

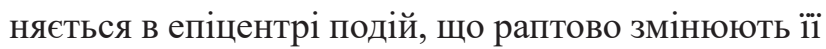
долю, потребуючи невідкладних дій і рішень.

Індивідуально-психологічні особливості особистості, різний життєвий досвід накладають свій неповторний відбиток на глибину, тривалість і складність кризових переживань. Особливості психічного сприймання, емоційної сфери особистості, самооцінки, рівень психічної саморегуляції, психологічна чутливість людини до всього, що відбувається навколо, відіграють не останню роль у входженні у кризову ситуацію та іiі переживанні. Переживання людиною кризи також тісно пов'язане зі ступенем усвідомлення кризового стану. Деякі люди мають змогу відверто зізнатися собі в гострих проблемах, які нагромадились, у погіршенні працездатності, появі соматичних симптомів, ускладненнях у спілкуванні, тривожності, дратівливості тощо. Інші, які не помічають наближення чи навіть розгортання кризової ситуації, намагаються сховатися від необхідності усвідомлення скрутних життєвих обставин і воліють захворіти або вдатися до вжи- вання алкоголю, щоб уникнути вирішення актуальних проблем. Усвідомлення кризового стану збільшується зі зростанням рівня особистісної зрілості, з розвитком здатності до рефлексії, які в кожної людини особливі, специфічні. Ці можливості залежать від індивідуального досвіду попереднього розв'язання складних життєвих колізій, i їx, безумовно, можна розвинути. Серед найнеприємніших кризових переживань варто згадати неможливість бачити, прогнозувати власне майбутнє. У скрутних життєвих обставинах майбутнє завжди звужується, перспектива втрачається, i тривога щодо завтрашнього дня, небажаних несподіванок, можливих неприємних сюрпризів починає негативно впливати на самопочуття, працездатність, стосунки з оточенням, смак до життя як такий $[5$, с. 43].

Сутність феномену життєвої кризи зумовлює постановку питання про ресурси подолання, пошук і актуалізацію психологічних властивостей, що потенційно дозволяли б не тільки знайти внутрішнє врівноваження у процесі проживання життєвих складнощів, але й відкритись до змін, зберегти бачення майбутнього, можливість антиципації та розуміння траєкторії розвитку подій у власному житті та соціальних контекстах. У цьому аспекті традиційно розглядається питання про значну роль адаптивності, що забезпечує пристосування особистості до змінених умов життя, навіть у вкрай важких обставинах (Ф. Березін, О. Маклаков, В. Розов та інші) [4].

Особистісні ресурси подолання складних життєвих ситуацій, як і особистісні ресурси взагалі, можна вважати багатовимірним феноменом, що визначається певними особистісними якостями людини, які сприяють досягненню значущих життєвих цілей у важких, психотравмувальних, кризових, непередбачуваних та неконтрольованих життєвих обставинах, актуалізуючись за необхідності для вирішення тих чи інших завдань. Отже, особистісні ресурси впливають на успішність соціально-психологічної адаптації особистості, зокрема й у кризових ситуаціях та складних обставинах життя. Варто наголосити на тому, що особистісні ресурси значною мірою визначаються здатністю до побудови інтегрованої поведінки. Чим вища здатність до інтеграції поведінки, тим більш успішне долання стресогенних ситуацій. Адаптаційні здібності людини залежать від психологічних особливостей особистості. Саме ці особливості визначають можливості адекватного регулювання фізіологічних станів. Чим розвиненіші адаптаційні ресурси, тим вища ймовірність 
того, що організм людини збереже нормальну працездатність і високу ефективність діяльності під час впливу психогенних чинників зовнішнього середовища.

Згідно 3 А. Маклаковим, адаптаційні можливості включають такі характеристики: нервово-психічну стійкість, рівень розвитку якої забезпечує толерантність до стресу; самооцінку особистості, що є ядром саморегуляції і визначає ступінь адекватності сприйняття умов діяльності і своїх можливостей; відчуття соціальної підтримки, що зумовлює почуття власної значущості для оточення; рівень конфліктності особистості; досвід соціального спілкування [2]. Отже, основні завдання, які постають перед особистістю в разі потрапляння у кризові ситуації, безпосередньо пов'язані 3 активним використанням психологічних, або ж адаптаційних, ресурсів.

Основні чинники, що впливають на особливості соціально-психологічної адаптації особистості у кризовій ситуації, на нашу думку, умовно можна поділити на дві групи: зовнішні та внутрішні (рис. 1). Вони можуть або сприяти успішній соціально-психологічній адаптації особистості у кризовій ситуації, зокрема завдяки опануванню себе, свого емоційного стану, саморегуляції, або ж, навпаки, порушувати іii.
До зовнішніх чинників відносимо ті, які не залежать від особистості, зокрема такі, як: сама психотравмувальна подія, або екстремальна ситуація, умови й обставини іiі виникнення, тривалість, соціальне оточення, наявність підтримки, або соціально-психологічної допомоги (iii професійність, вчасність тощо), якщо цього вимагають обставини тощо. У разі виникнення надзвичайних ситуацій значний вплив на соціально-психологічну адаптацію особистості в таких обставинах можуть мати масові соціально-психологічні явища, а саме паніка, чутки, поява фейків, які здатні дезорганізувати, дезорієнтувати людину, порушують пристосування до зміненої реальності.

Внутрішні чинники, які впливають на процес соціально-психологічної адаптації особистості у кризовій ситуації, пов'язані 3 особистісними характеристиками. Від них залежить успішність соціально-психологічної адаптації особистості та вибір ефективних копінг-стратегій. Зокрема, до них належать: індивідуально-психологічні особливості людини, особливості когнітивної, емоційної сфери особистості, психічна саморегуляція та навички самоконтролю, самооцінка, особистісна зрілість, життєвий досвід тощо. Так, інфантильність особистості, невпевненість у собі, неготовність брати на себе відповідальність,

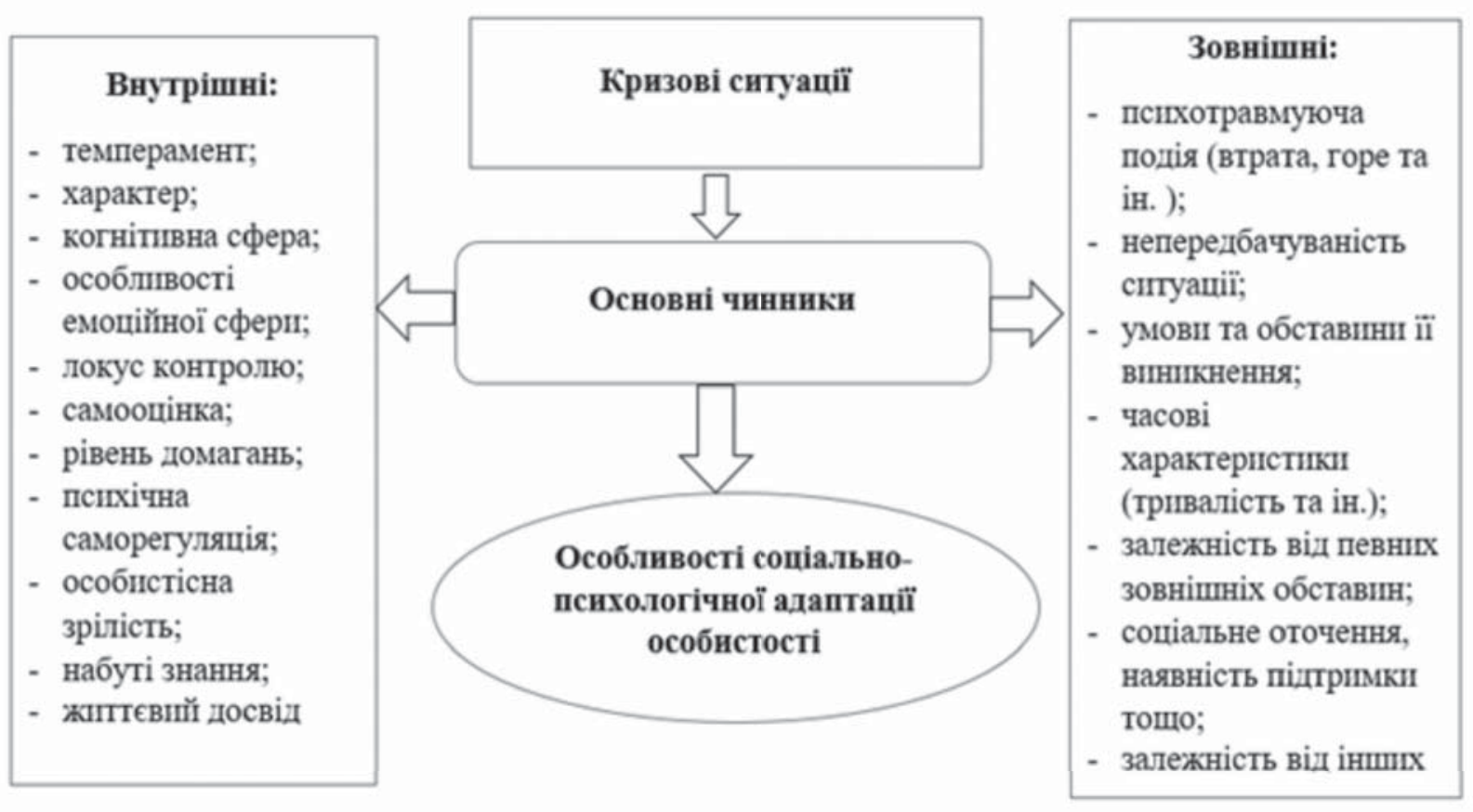

Рис. 1. Чинники, що впливають на особливості соціально-психологічної адаптації особистості у кризовій ситуації 
залежність від інших перешкоджають особистості успішно адаптуватися у кризовій ситуації, опанувати себе, критично мислити та формувати стратегії поведінки в ситуації, що виникла.

Знання та врахування цих чинників визначають вибір поведінкових стратегій подолання проблем і кризових ситуацій, можуть передбачити «ціну» копінгу (наскільки особистісні ресурси людини будуть виснажені або ж, навпаки, збережені в разі їі намагання впоратися зі складною життєвою ситуацією).

У підсумку варто зазначити, що у кризових ситуаціях активізуються адаптаційні ресурси особистості, які дозволяють людині пристосуватися до нових обставин, зміненої реальності, створюють умови для їх «прийняття» та переосмислення. На початковому етапі кризової ситуації особистість схильна мислити стереотипно та шаблонно, що деякою мірою можна вважати захисною реакцією психіки на тлі переваги емоційної складової частини реагування на ситуацію та іiі сприйняття, оскільки раціональні можливості психіки у кризовій ситуації не можуть повною мірою бути розкритими через домінування емоцій. Згодом, коли емоційний заряд спадає, людина більшою мірою стає спроможною мислити раціонально й об'єктивно проаналізувати ситуацію, що склалася.

Отже, до особливостей соціально-исихологічної адаптації особистості в умовах кризових ситуацій можна віднести такі:

1. Зміна «картини» зовнішнього світу, що зумовлено зміненими обставинами життя та соці- альної реальності, а також особливостями індивідуального їі сприйняття.

2. Переоцінка життєвих цінностей особистості, пріоритетів, зміна когніцій власного «Я».

3. Активізація стереотипів, шаблонів мислення у сприйманні соціальної дійсності, міжособистісній взаємодії та поведінці.

4. Перебудова власної поведінки, зміна стратегії взаємин з оточенням, що викликано життєвою необхідністю. Усе це залежить від індивідуально-психологічних особливостей людини, типу темпераменту, рис характеру, самооцінки тощо.

Звичайно, різні люди по-різному можуть сприймати ту саму кризову ситуацію, по-різному реагуватимуть на неї (сила, глибина переживань), по-різному будуть пристосовуватись та виробляти стратегії власної поведінки.

Висновки. Якщо узагальнити вищезазначене, можна стверджувати, що особливості соціальнопсихологічної адаптації особистості у кризовій ситуації визначаються складністю самої ситуації (основні життєві цінності, яких вона стосується), основними причинами іiі виникнення (природні чинники, непереборні обставини, стан фізичного та психічного здоров’я людини, психосоматизація тощо), особливостями соціальної дійсності та зміненої реальності (соціальне оточення, соціальна підтримка, фахова соціально-психологічна допомога тощо), а також індивідуально-психологічними особливостями особистості.

Перспективним для подальших наукових досліджень $є$ вивчення конструктивних копінгстратегій подолання кризових ситуацій.

\section{Список літератури:}

1. Зливков В., Лукомська С., Федан О. Психодіагностика особистості у кризових життєвих ситуаціях. Київ : Педагогічна думка, 2016. С. 4-8.

2. Казібекова В. Психологічні ресурси особистості у кризових ситуаціях. Особистість у кризових умовах та критичних ситуаціях життя : матеріали IV Міжнародної науково-практичної конференції, 22-23 лютого 2018 р. Суми : Вид-во СумДПУ імені А.С. Макаренка, 2018. С. 48-49.

3. Кризова психологія : навчальний посібник / за заг. ред. О. Тімченка. Харків : НУЦЗУ, 2010. 401 с.

4. Кузнєцова О. Спрямованість адаптивності як ресурс подолання життєвої кризи. Особистість y кризових умовах та критичних ситуаціях життя : матеріали IV Міжнародної науково-практичної конференції, 22-23 лютого 2018 р. Суми : Вид-во СумДПУ імені А.С. Макаренка, 2018. С. 61-63.

5. Особистість як суб'єкт подолання кризових ситуацій: психологічна теорія і практика : монографія / за ред. С. Максименка, С. Кузікової, В. Зливкова. Суми : Вид-во СумДПУ імені А.С. Макаренка, 2017. 540 c.

6. Ромек В., Конторович В., Крукович Е. Психологическая помощь в кризисных ситуациях. СанктПетербург : Речь, 2007. 258 с.

7. Титаренко Т. Испытание кризисом. Одиссея преодоления. Киев : Людопринт Украина, 2009. 277 с.

8. Ткачишина О. Кризові ситуації: адаптаційні ресурси особистості та соціальні стереотипи. Теорія і практика сучасної психологї : збірник наукових праць. Запоріжжя, 2020. № 1. Т. 3. С. $116-120$. 


\section{Tkachyshyna O.R. FEATURES OF SOCIO-PSYCHOLOGICAL ADAPTATION OF THE INDIVIDUAL IN CRISIS SITUATIONS}

The article is devoted to the problem of social and psychological adaptation of the individual in crisis situations. The problem of socio-psychological adaptation of the individual at the present stage of development of society is relevant and will remain so, because the world we live in is changing, human society is changing, and finally, the personality is changing. Personal changes are largely due to the process of socio-psychological adaptation of the individual to social transformations and transformations, which is especially important in crisis situations. The life of a modern person is characterized by saturation, heterogeneity and variability, which creates certain psychological difficulties in life. Man is forced to adapt to new conditions and requirements imposed on him by society, science, technology. In recent decades, thanks to scientific and technological progress, these changes have become very rapid. In addition, they make society more aggressive towards people. Social interactions are often a major source of serious conflict and stress for a person and can negatively affect physical and mental health. Modern life is full of various stressors that affect both physical and mental health, and prolonged exposure to stressful situations can lead to a life crisis. Personality is faced with the need to overcome stress, solve problems, solve complex problems that life itself presents to it. The article reveals the psychological characteristics of crisis situations, crisis situations, identifies the main content of the crisis as a whole. The main factors influencing the features of socio-psychological adaptation of the individual in a crisis situation are identified. The importance of activating the adaptive resources of the individual in crisis situations is emphasized. An important role in this context is played by individual psychological characteristics of the individual, his life experience, knowledge, which are crucial in developing constructive coping strategies for overcoming crisis situations.

Key words: social and psychological adaptation, crisis, crisis situations, crisis states, adaptation resources. 